\title{
The Impact of Debt Funding Sources on Liquidity of Companies in Food Industry
}

\author{
Markéta Šeligová, Ivana Koštuříková
}

School of Business Administration in Karvina, Silesian University in Opava, Karviná, Czech Republic

\begin{abstract}
The aim of this article is to determine the impact of debt funding sources structure on liquidity of companies in food industry in the Czech Republic from 2006 to 2016. With the purpose to fulfill the aim, we examine existence and character of relationship between the debt funding sources structure (long-term loans, short-term loans, other long-term liabilities, other short-term liabilities, debt equity ratio) and liquidity of the companies (cash ratio, quick ratio and current ratio) in food industry in the Czech Republic. The relationship between debt funding sources structure and liquidity of companies is tested through correlation analysis, Granger causality test and generalized method of moments (GMM). The liquidity of companies was positively influenced by the long-term loans in companies (cash ratio and quick ratio) in food industry in the Czech Republic. The results also indicate that there is the negative impact of other current liabilities on liquidity of companies (cash ratio, quick ratio and current liquidity) in food industry in the Czech Republic.
\end{abstract}

\section{Keywords}

Debt funding sources, generalized method of moments, Granger causality test, liquidity, long-term bank loans.

Šeligová, M. and Koštuř́ková, I. (2019) “The Impact of Debt Funding Sources on Liquidity of Companies in Food Industry", AGRIS on-line Papers in Economics and Informatics, Vol. 11, No. 3, pp. 91-104. ISSN 1804-1930. DOI 10.7160/aol.2019.110309.

\section{Introduction}

Industry is an important branch of the Czech economy and employs $38 \%$ of all economically active inhabitants. The main industrial sector in the Czech Republic includes the chemical, engineering, food and steel industries. Other major industries are the energy, construction and consumer industries. Less important sectors are the arms industry and glass industry (which has a long tradition in the Czech Republic). Industry accounts for $38 \%$ of the Czech economy. According to Panorama of food industry (2017), the food and beverage industry is one of the leading industries in the Czech Republic. Its significance is primarily due, to the fact that it provides for the nutrition of the population. The basic raw materials of the Czech food industry are domestic agricultural products, forestry and water products and imported raw materials. In the Czech Republic, food production and beverage production account for $2.7 \%$ of GDP.

As stated by the Institute of Agricultural Economics and Information (2017), the production of food products in the Czech Republic belongs to the major branches of the manufacturing industry as well as to the whole of the European Union. This is mainly due to deliveries for the domestic market, which ensures the nutrition of the population through the production and sale of healthy and safe foods, which is controlled by the supervising institutions including the quality of the products. It turns out that not only the price but also the quality decides to buy a particular food. Although foreign trade in food products has a negative balance, exports have considerable importance in the complicated situation in some territories. This fact proves the quality and competitiveness of Czech food production both in the European and world markets.

Between 2007 and 2009, almost all sectors of the Czech Republic were affected by the global economic crisis. Similarly, it has also been in the manufacture of food products. According to the Ministry of Industry and Trade 
of the Czech Republic (2014), the Czech Republic recorded a decline in industrial output, a drop in new orders, a fall in household final consumption expenditure, a fall in investment and a rise in unemployment. After the bout of the crisis period, the Czech economy gradually revived. The revival of the Czech economy was affected by the growing consumption of households and the domestic production of food goods. The financial health of, in particular, larger companies in the food industry has boosted a higher trade margin, which has grown by almost a fifth, twice the pace for the entire manufacturing industry.

Despite the fact that the food industry has achieved favorable economic results in recent years, investments have been and are being covered by credit sources and, in part, the direct entry into capital of other business entities, both domestic and foreign. The decline in profitability combined with a high level of investment led to an increase in their indebtedness in individual businesses. The high level of indebtedness of the food industry and its continuous increase is due in particular to the growth of bank loans and liabilities to suppliers, especially agricultural holdings. The highest indebtedness rate was relatively high in sectors with low profitability, such as the dairy industry, the sugar industry, the milking industry and the starch industry. This high level of indebtedness is a risk to their own businesses, but also to their creditors, especially the primary agricultural producers who have long-term receivables. This high indebtedness raises the risk that the company will be unable to pay, which can lead to corporate bankruptcies. In order for a company to be able to pay, it must have the considerable liquidity needed to finance its investment activities and to meet its corporate obligations. On the other hand, if a company gets into liquidity problems, it can raise money through further debt (for example, bank loans).

For many years, asset liquidity in relation to the optimal level of debt or debt has been a controversial issue in financial studies. Generally in some countries liquid companies have used higher levels of debt, while in other countries these companies have been more funded by equity. Liquid companies are those companies that are able to convert their assets into cash and cover them in due time, in the required form and at the required location, with all their due liabilities at a minimum cost. Typically, these companies hold more current assets such as cash, financial assets, stocks and receivables. The relationship between liquidity and the capital structure of an enterprise may be different. Companies with a higher liquidity ratio may have a relatively higher debt ratio due to the greater ability to cover their short-term liabilities at maturity. This would lead to a positive relationship between the liquidity of the firm and its indebtedness or its debt ratio. On the other hand, enterprises with larger liquid assets may use these assets to finance their investments, which results in a negative relationship between the liquidity of the company and its leverage effect.

Stulz (1990) argues that companies may have difficulty finding new sources to fund their projects at a time when high leverage may lead to a reduction or loss of their financial flexibility. However, a certain level of debt or debt does not necessarily mean a negative phenomenon. If the debt is regularly monitored, the volume of debt is under control, and borrowed funds are used appropriately, leverage can lead to an increase in return on investment. High debt companies should invest in more liquid assets and assets that generate short-term cash flows (Peyer and Shivdasani, 2001; Ahn et al., 2006; Campello, 2003; Campello and Fluck 2005). Companies with high indebtedness will invest in safer and less risky investments or projects (Andrade and Kaplan, 1998; Eisdorfer (2008). Sufi (2009), looking at the information on whether a firm has access to credit, has found that businesses with very limited access to credit have a particularly good chance of saving cash from cash flows. This savings can be achieved through a so-called tax shield, which can be considered one of the benefits of borrowing by the company.

Morellec (2001), who believes that companies leverage a leverage effect because of the aforementioned tax shield that companies can use to their advantage, is accustomed to this claim. This idea was also supported by Graham (2000), who takes the view that most companies could leverage to obtain the corresponding tax benefits that are linked to debt burden without a clear increase in the costs associated with the financial troubled enterprise. Almeida et al. (2004) believe that the leverage effect 
leads companies to expect higher external financing costs in the future, leading to the use of investment towards safer projects. In addition, they also indicate another reason why companies limit their leverage. Higher leverage leads businesses to invest in safer and more liquid projects, but potentially less profitable.

For example, Al-Najjar and Belghitar (2011) looked at debt financing, which considered that a certain amount of leverage and profitability of an enterprise determined and influenced the decision to have a certain amount of the most liquid cash. In line with this idea, Baskin (1987) concludes that companies with a higher leverage effect will accumulate liquidity due to a higher probability of financial distress. In general, it is proposed that the volume of liquid or cash resources be reduced as the company's debt rises. Ferreira and Vilela (2004) suggest that firms with high levels of debt are less able to dispose of a sufficient volume of highly liquid assets. This is because they are better monitored than companies with relatively low debt or debt. Opler, Pinkowitz, Stulz and Williamson (1999) found a negative relationship between corporate debt and corporate liquidity on a sample of US non-financial corporations using panel regression analysis.

Anderson (2002) examined through regression analysis the factors influencing the holding of liquid assets. It identified the relationship between corporate liquidity and capital structure. As part of his research, he believed that if the firm relied heavily on and using high levels of debt financing, it tends to have a high level of liquid assets. The high level of debt financing tends to be associated with a high level of holding of liquid assets. The results have shown a positive relationship between the leverage effect and the liquidity of the company, where the leverage effect will increase the company's liquidity. This leads the author to identify a possible link where the high level of debt leads to high liquidity, which will lead to slow growth of the company. This resulting relationship is in line with the presence of a preventive motif of holding liquid assets in companies that maintain high leverage as a permanent feature of their capital structure. Furthermore, the negative relationship between short-term leverage and liquidity was demonstrated. The reason is that short-term debt and liquid assets can be substitutes in the sense that a company facing a low cash flow will react to this either by drawing on available liquid assets or by accumulating short-term debt or by combining both of these options.

Sharlija and Harc (2012) concluded that the negative relationship between corporate liquidity and short-term leverage is more significant than the positive relationship between corporate liquidity and long-term leverage. They believed that the more the company is liquid, the less it is indebted. The authors also believe that long-indebted companies have a larger volume of liquid assets and can be considered as more liquid. The results of the study also showed a negative relationship between cash and short-term or long-term leverage. The problem of debt funding sources and liquidity of companies has been dealt with in a number of authors in their studies. An overview of the studies dealing with similar issues, including the variables and methods used, are presented in the Table 1.

From the above-mentioned literature review, it is clear that there has been no clear impact of debt funding sources on corporate liquidity. For this reason, the aim of this article is to determine the impact of debt funding sources structure on liquidity of companies in food industry in the Czech Republic from 2006 to 2016. With the purpose to fulfill the aim, we examine existence and character of relationship between the debt funding sources structure (long-term loans, short-term loans, other longterm liabilities, other short-term liabilities, debt equity ratio) and liquidity of the companies in food industry in the Czech Republic. The relationship between debt funding sources structure and liquidity of companies will be tested through correlation analysis, Granger causality test and generalized method of moments (GMM).

In order to achieve the goal, the following research questions will be identified and evaluated:

- What is the relationship between the debt funding sources structure and liquidity of companies in food industry in the Czech Republic from 2006 to 2016 ?

The first part of this article will include a literature review. The second part of this article will focused on data and methodology. The third part of this article will contain results. Last part of this article will conclude results and discussion. 


\begin{tabular}{|c|c|c|c|}
\hline Authors & Methods & Variables & Results \\
\hline Růčková (2014) & - $\quad$ correlation analysis & $\begin{array}{l}\text { Return on equity, quick ratio (L2), gross } \\
\text { domestic product }\end{array}$ & $\begin{array}{l}\text { Return on equity }(+/-) \text {, } \\
\text { gross domestic product }(+/-)\end{array}$ \\
\hline Růčková (2015) & - $\quad$ GMM method & $\begin{array}{l}\text { Debt equity ratio, return on equity, current } \\
\text { ratio (L3) }\end{array}$ & Debt equity ratio $(+/-)$ \\
\hline Šeligová (2017) & $\begin{array}{l}\text { - } \quad \text { correlation analysis } \\
\text { - } \quad \text { regression analysis }\end{array}$ & $\begin{array}{l}\text { The share of fixed assets in total assets, } \\
\text { return on assets, return } \\
\text { on equity, debt equity ratio }\end{array}$ & $\begin{array}{l}\text { The share of fixed assets } \\
\text { in total assets }(-) \text {, return } \\
\text { on equity }(+) \text {, debt equity } \\
\text { ratio (-) }\end{array}$ \\
\hline Šeligová (2018) & $\begin{array}{l}\text { - } \quad \text { correlation analysis } \\
\text { - } \quad \text { GMM method }\end{array}$ & $\begin{array}{l}\text { The share of fixed assets in total assets, } \\
\text { return on assets, return on equity, debt equity } \\
\text { ratio, equity ratio }\end{array}$ & $\begin{array}{l}\text { Return on assets }(-) \text {, return } \\
\text { on equity }(+) \text {, equity ratio }(+)\end{array}$ \\
\hline $\begin{array}{l}\text { Kim, Mauer a Sherman } \\
\text { (1998) }\end{array}$ & $\begin{array}{l}\text { - } \quad \text { correlation analysis } \\
\text { - } \quad \text { regression analysis }\end{array}$ & $\begin{array}{l}\text { Growth opportunities, cash flow volatility, } \\
\text { debt funding or debt, cash flow } \\
\text { and bankruptcy risk }\end{array}$ & $\begin{array}{l}\text { Growth opportunities }(+) \text {, } \\
\text { debt equity ratio(-) }\end{array}$ \\
\hline $\begin{array}{l}\text { Opler, Pinkowitz, Stulz } \\
\text { a Williamson (1999) }\end{array}$ & $\begin{array}{l}\text { - panel regression } \\
\text { analysis }\end{array}$ & $\begin{array}{l}\text { Cash, asset value, market value of a firm, } \\
\text { science and research expenditure, capital } \\
\text { expenditure, cash flow, net working capital, } \\
\text { shareholder payout and leverage }\end{array}$ & $\begin{array}{l}\text { Growth opportunities }(+) \text {, } \\
\text { debt }(-)\end{array}$ \\
\hline Anderson (2002) & - $\quad$ regression analysis & $\begin{array}{l}\text { Return on assets, long-term loans, medium- } \\
\text { term loans, short-term loans, science } \\
\text { and research expenditure, cash flow, liquidity }\end{array}$ & $\begin{array}{l}\text { Long-term leverage }(+) \text {, } \\
\text { short-term leverage }(-)\end{array}$ \\
\hline Mehar (2005) & - $\quad$ correlation analysis & $\begin{array}{l}\text { Fixed assets, net profit after tax, retained } \\
\text { earnings }\end{array}$ & $\begin{array}{l}\text { Fixed assets }(+) \text {, net profit }(+) \text {, } \\
\text { retained earnings }(-)\end{array}$ \\
\hline Shah (2012) & - $\quad$ correlation analysis & Return on assets & Return on assets (-) \\
\hline Šarlija a Harc (2012) & - correlation analysis & $\begin{array}{l}\text { Share of retained earnings on capital, } \\
\text { leverage }\end{array}$ & Leverage (-) \\
\hline Al-Najjar (2013) & - $\quad$ regression analysis & $\begin{array}{l}\text { Impact of the capital structure, leverage, } \\
\text { profitability, company size, dividend policy }\end{array}$ & \\
\hline Trippner (2013) & - correlation analysis & Return on assets, return on equity & $\begin{array}{l}\text { Return on assets }(+,-) \text {, } \\
\text { return on equity }(+,-)\end{array}$ \\
\hline Miloş (2015) & $\begin{array}{l}\text { - panel regression } \\
\text { analysis }\end{array}$ & $\begin{array}{l}\text { Share of total debt on total liabilities, return } \\
\text { on assets, share of fixed assets in total assets, } \\
\text { size of firm }\end{array}$ & Leverage (-) \\
\hline
\end{tabular}

Source: own processing

Table 1: Overview of selected empirical studies related to the relationship between the funding sources structure and liquidity of companies.

\section{Materials and methods}

To determine the relationship between the debt funding sources structure and the liquidity of companies in the food industry, financial data was used, which was drawn from the Amadeus database. This database includes data from the annual reports of individual companies in Europe. To fulfill the objective of this article, data from annual reports of individual companies in food industry in the Czech Republic were selected.

To determine the relationship between debt funding sources structure and liquidity of companies, medium sized companies, large companies and very large companies were selected.

The Amadeus database divides companies by size as follows:
- A very large companies with operating revenues of more than EUR 100 million, total assets of more than EUR 200 million and more than 1000 employees.

- A large companies with operating revenues of more than EUR 10 million, total assets of more than EUR 20 million and more than 150 employees.

- A medium-sized companies with operating revenues of more than EUR 1 million, total assets greater than EUR 2 million and more than 15 employees.

- Small companies are considered to be enterprises that do not meet the criteria set for medium-sized enterprises.

The dataset cover the period 2006-2016. All data 
and time series are on annual frequency. The sample of analyzed companies includes 306 companies in food industry of which 157 are medium-sized companies, 131 are large companies and 18 are very large companies. The data from Amadeus database are the basis for the application of correlation analysis, Granger causality test and generalized method of moments. On the other hand, the data used to illustrate the development of liquidity for the entire food industry in the Czech Republic was obtained from the Ministry of Industry and Trade of the Czech Republic and the Amadeus database. First, the data was processed in Microsoft Excel and then econometric software Eviews 8 was used to determine the relationship between debt funding sources structure and liquidity companies. The Amadeus database includes the division of companies only into medium-sized companies, large companies and very large companies.

Recommendation 2003/261/ European Directive defines small companies as companies with employees less than 50 employees annual turnover of less than EUR 10 million or balance sheet total of less than EUR 10 million.

For this reason, medium-sized companies can be identified to a certain extent by selecting them from the Amadeus database with small companies according to Recommendation 2003/261 / European Directive.

In order to answer the identified research question, the following variables were selected, the selection of which was based primarily on the abovementioned literature review. The description of the variables used is shown in Table 2.

Three ratios are used to express the liquidity of the company and characterize the liquidity of the company according to the balance sheet. The company's liquidity is expressed using the cash ratio, the quick ratio or the current ratio. Derivatives characterizing the amount of short-term and longterm bank loans, the debt equity ratio indicator, and the volume of other short and long-term liabilities such as trade payables, bond liabilities, payables to employees (payables), etc., are used to express the debt financing sources structure.

\begin{tabular}{|c|c|c|c|}
\hline Abbreviation & Description & Calculation & Calculation \\
\hline L1 & Cash ratio & $\frac{\text { cash }}{\text { current liabilities }}$ & $\frac{L N 71(B S, A)}{L N 37(B S, L)}$ \\
\hline $\mathbf{L 2}$ & Quick ratio & $\frac{\text { current assets }- \text { inventories }}{\text { current liabilities }}$ & $\frac{L N 37-L N 38(B S, A)}{L N 37(B S, L)}$ \\
\hline L3 & Current ratio & $\frac{\text { current assets }}{\text { current liabilities }}$ & $\frac{L N 37(B S, A)}{L N 37(B S, L)}$ \\
\hline STL & $\begin{array}{l}\text { Short-term } \\
\text { loans }\end{array}$ & $\frac{\text { short term bank loans }}{\text { total assets }}$ & $\frac{L N 50(B S, L)}{L N 1(B S, A)}$ \\
\hline LTL & $\begin{array}{l}\text { Long-term } \\
\text { loans }\end{array}$ & $\frac{\text { long term bank loans }}{\text { total assets }}$ & $\frac{L N 35(B S, L)}{L N 1(B S, A)}$ \\
\hline DER & $\begin{array}{l}\text { Debt equity } \\
\text { ratio }\end{array}$ & $\frac{\text { debt }}{\text { equity }}$ & $\frac{L N 24(B S, L)}{L N 2(B S, L)}$ \\
\hline OCL & $\begin{array}{l}\text { Other current } \\
\text { liabilities }\end{array}$ & $\frac{\text { other current liabilities }}{\text { total assets }}$ & $\frac{L N 46-L N 50(B S, L)}{L N 1(B S, A)}$ \\
\hline ONCL & $\begin{array}{l}\text { Other non- } \\
\text { current } \\
\text { liabilities }\end{array}$ & $\frac{\text { other non-current liabilities }}{\text { total assets }}$ & $\frac{L N 31-L N 35(B S, L)}{L N 1(B S, A)}$ \\
\hline
\end{tabular}

Note: $\mathrm{LN}=$ Line Number, $\mathrm{BL}=$ Balance Sheet, $\mathrm{A}=$ Assets, $\mathrm{L}=$ Liabilities

Source: own proceeding 
The liquidity ratio is very important indicator because liquid company only is able to pay its payables. If the company has a sufficient amount of funds for payment of its current liabilities, the company will be liquid. An excessively high value of liquidity is usually accompanied by lower values of equity (return on equity) that is associated with a conservative approach. On the other hand, companies that have too low levels of liquidity typically use debt sources for financing their activities.

Debt equity ratio (leverage) measures debt sources to equity. The higher value of the debt equity ratio, the higher ratio of debt sources to equity. This fact can indicate a higher risk for creditors. The value of debt equity ratio 1 indicates that equity and debt sources are involved in the financing of companies in the same amount. Higher debt represents a higher level of risk of companies. On the other hand, higher debt may mean a larger volume of funding sources because the costs of external funding tend to be cheaper than costs of equity. Companies that have too low levels of liquidity typically use debt sources for financing their activities. For this reason, we can expect a negative relationship between liquidity of companies and debt equity ratio.

Table 3 shows the basic descriptive characteristics of companies in food industry in the Czech Republic, where maximum and minimum capture the maximum value and the minimum value of liquidity of companies and debt funding sources structure. The standard deviation shows a standard deviation of the value from their arithmetic mean. Median is a value that divides a series of ascending ranked results into two equally large halves.

Due to the large number of data, this data was processed into panel data by industry and period. These panel data were subsequently used in the correlation analysis, Granger causality test and Generalized Method of Moments (GMM).

According to Cohena (2014), the correlation analysis is a suitable method for the initial identification (estimation) of the functional relationship between a particular explanatory and explanatory variable. The correlation relationship can be expressed using the Pearson correlation coefficient, which may take the following form:

$$
P=\frac{\Sigma\left(x_{i}-\bar{x}\right)\left(y_{i}-\bar{y}\right)}{(n-1) s_{x} s_{y}}=\frac{\Sigma\left(x_{i}-\bar{x}\right)\left(y_{i}-\bar{y}\right)}{\sqrt{\Sigma\left(x_{i}-\bar{x}\right)^{2} \Sigma\left(y_{i}-\bar{y}\right)^{2}}}
$$

Where $X$ represents the mean value of the enterprise solvency matrix represented by the selected enterprise liquidity indicator, $Y$ is the mean of the matrix of the values of the individual financial indicators related to the structure of the sources of financing (explanatory variables) and $n$ the number of observations. Pearson's correlation coefficient is based on the calculation by entering the covariance of the variables $X$ and $Y$ into the numerator, and then into the denominator the product of the standard deviations of the variables $X$ and $Y$, which is defined as the root of the variance of the random variables $X$ and $Y$.

The resulting correlation analysis values range from -1 to 1 when the values approaching 1 indicate a positive dependence (positive linear correlation) between the analyzed variables, the values approaching -1 have a completely opposite negative relationship (negative linear correlation). The values near 0 show the mutual independence of the variables (zero linear correlation), where the dependency can't be determined unequivocally (there is no linear dependence confirmed here, but it can be a non-linear dependence between the analyzed variables). The variables are uncorrelated in this case. According to Evans (1996) the values of the correlation coefficient in the following range indicate:

- 0 to 0.19 very weak correlation

- 0.2 to 0.39 weak correlation

- $\quad 0.4$ to 0.59 middle correlation

\begin{tabular}{|l|c|c|c|c|c|}
\hline & Maximum & Minimum & Standard deviation & Mean & Median \\
\hline L1 & 996.93 & -29.69 & 28.03 & 2.20 & 0.13 \\
\hline L2 & 4113.25 & -139.85 & 82.72 & 6.09 & 1.65 \\
\hline L3 & 7736.17 & -223.06 & 149.55 & 9.45 & 2.53 \\
\hline STL & 0.98 & -0.01 & 0.11 & 0.08 & 0.02 \\
\hline LTL & 0.75 & -0.07 & 0.14 & 0.13 & 0.05 \\
\hline DER & 519.28 & -606.50 & 24.33 & 1.97 & 0.89 \\
\hline OCL & 4.26 & -0.02 & 0.31 & 0.44 & 0.39 \\
\hline ONCL & 2.54 & -0.02 & 0.19 & 0.11 & 0.04 \\
\hline
\end{tabular}

Source: own proceeding according to Amadeus Database 


\section{- $\quad 0.6$ to 0.79 strong correlation}

- $\quad 0.8$ to 1 very strong correlation

The statistical significance of the correlation coefficient, which can be tested at $1 \%, 5 \%$ and $10 \%$ significance, plays an important role in determining the relationship between variables. Using correlation analysis and the correlation coefficient, the relationship between the variables, including their resulting direction, ie whether they are positive, negative or zero correlations, can be determined. However, it is not possible to determine which variable affects another variable.

For this reason, the Granger causality test will be used to determine which variable may affect another variable. In accordance with the article, we focus using Granger causality test to determine, whether debt founding sources structure affects the liquidity of companies and which specific variables related to debt funding sources structure affect the liquidity of food companies. To determine the existence of short-term relationships between two variables, Granger's causality test, which works with stationary rows and delays used in cointegration analysis, can be used. Granger's causality takes into account that the past can influence the future. Variable $X$ has a causal effect (in a granger sense) on Y if past X values can help explain Y.

In the case of Granger's causality, the aim is to reject the zero hypothesis that there is no causal relationship between the variables studied. Engle and Grange (1987), in their study, quantify Granger causality by the following equations (2) a (3), where $Y_{t}$ and $X_{t}$ represent corporate liquidity and debt funding sources structure, $\varepsilon_{t}$ error or residual component, $\beta_{0}$ and $\varphi_{0}$ constants of causal equations, $\beta_{1 t}, \beta_{2 t}, \varphi_{1 t}$ and $\varphi_{2 t}$ intersections with axes $X$ and $Y$.

$$
\Delta Y_{t}=\beta_{0}+\sum_{i=1}^{\sigma} \beta_{1 i} \Delta Y_{t-i}+\sum_{i=1}^{\gamma} \beta_{2 i} \Delta X_{t-1}+\varepsilon_{1 t}
$$

$\Delta X_{t}=\varphi_{0}+\sum_{i=1}^{\gamma} \varphi_{1 i} \Delta X_{t-i}+\sum_{i=1}^{\gamma} \varphi_{2 i} \Delta Y_{t-1}+\varepsilon_{2 t}$

Using the correlation analysis and the correlation coefficient, the relationship between the variables can be determined. However, it is impossible to determine how strong the dependence between these variables is, and how is a causal relationship or link between them that examines the relationship between the cause and its consequences within the variables analyzed by us. By contrast, using the Granger causality test, it is only possible to determine which variable may affect another variable.
However, it is impossible to determine how strong the dependence between these variables is, and how is a causal relationship or link between them that examines the relationship between the cause and its consequences within the variables analyzed by us. For this reason, a generalized method of moments (GMM method) will be used to determine the causal relationship between the variables and to determine the dependence of the endogenous variable on the exogenous variables.

According to Prucha (2014), the problem of panel data is mainly when individual panel data are part of a shorter time series and are unsuitable for the use of least squares in terms of panel regression. According to him, the Generalized Method of Moments (GMM method) is a suitable method for examining the functional relationships between variables that are organized into such panel data.. On the other hand, the disadvantage is the fact that it is not possible to test the given data within the basic assumptions of the smallest square method, ie heteroskedasticity, autocorrelation, normality and multi-collinearity and stationarity.

In order to ensure sufficient reporting ability, all variables will be tested for their statistical significance (for significance levels of $1 \%, 5 \%$ and $10 \%$ ). In addition, the robustness of the model will be verified using Sargan / Hansen J-test, which determines to what extent the method is capable of delivering the same results even under load by slight parameter changes. The model is robust in this regard if the results of the Sargan / Hansen test are greater than 0.05 .

The relationship between the debt financing structure and the liquidity of the bonds can be expressed using the following equation, which is in line with Hall (2005):

$$
\begin{aligned}
L_{i t}= & \alpha_{1}+\beta_{1} * \Delta L_{i t-1}+\beta_{2} * X_{1 i t}+\beta_{3} * X_{2 i t}+ \\
& \cdots+\beta_{n} * X_{n i t}+\varepsilon_{i t}
\end{aligned}
$$

where $L_{i t}$ depicts a dependent variable that is presented through selected liquidity indicators (current ratio $L_{3}$, quick ratio $L_{2}$ and cash ratio $L_{1}$ ) $i^{\text {th }}$ company within the Czech Republic in time , $\Delta L_{i t-1}$ is an explanatory variable that represents a delayed value $L$ from the previous year, $X n_{i t}$ it includes explanatory variables for which they are considered short-term loans, long-term loans, other current liabilities and other non-current liabilities. Symbols and represent the constant of the model and the residual component of the model within the generalized method of moments (GMM method). 


\section{Results and discussion}

Before using the selected methods to determine the relationship between the debt funding structure and the liquidity of companies in food industry the Czech Republic, it is necessary to find out how the liquidity of companies in food industry in the Czech Republic has developed at a general level (total industry) and in our sample of analyzed companies. Data for the entire industry was drawn from the database of the Ministry of Industry and Trade of the Czech Republic.

It can be seen from Figure 1 that the liquidity (current liquidity L3, quick liquidity L2 and cash liquidity L1) of the analyzed sample of companies in food industry in the Czech Republic developed almost evenly throughout the analyzed period. The liquidity value of the analyzed companies exceeded the diametrically recommended liquidity values. If we compare these liquidity values with the values of all companies in food industry in the Czech Republic, we can say that the liquidity values (current liquidity L3, quick liquidity L2 and cash liquidity L1) of the analyzed company sample exceeded the liquidity values of all companies several times in food industry in the Czech Republic throughout the analyzed period. Regarding the trend of liquidity values of all companies in food industry in the Czech Republic, it can be stated that their liquidity values (current liquidity L3, quick liquidity L2 and cash liquidity L1) showed an alternate development trend throughout the analyzed period. Liquidity indicators (L3, L2 and L1) showed an upward trend until 2009. After this year, liquidity indicators dropped mainly due to financial crises, thanks to which businesses got into solvency problems. The Table 4 reflects the degree of interdependence of monitored parameters in food industry in the Czech Republic using correlation analysis.

It can be seen from Table 4 that a statistically significant relationship between cash liquidity and short-term loans, debt ratios, other current liabilities and other non-current liabilities has been demonstrated at a materiality level of $1 \%$ and $5 \%$. The results showed a negative weak correlation

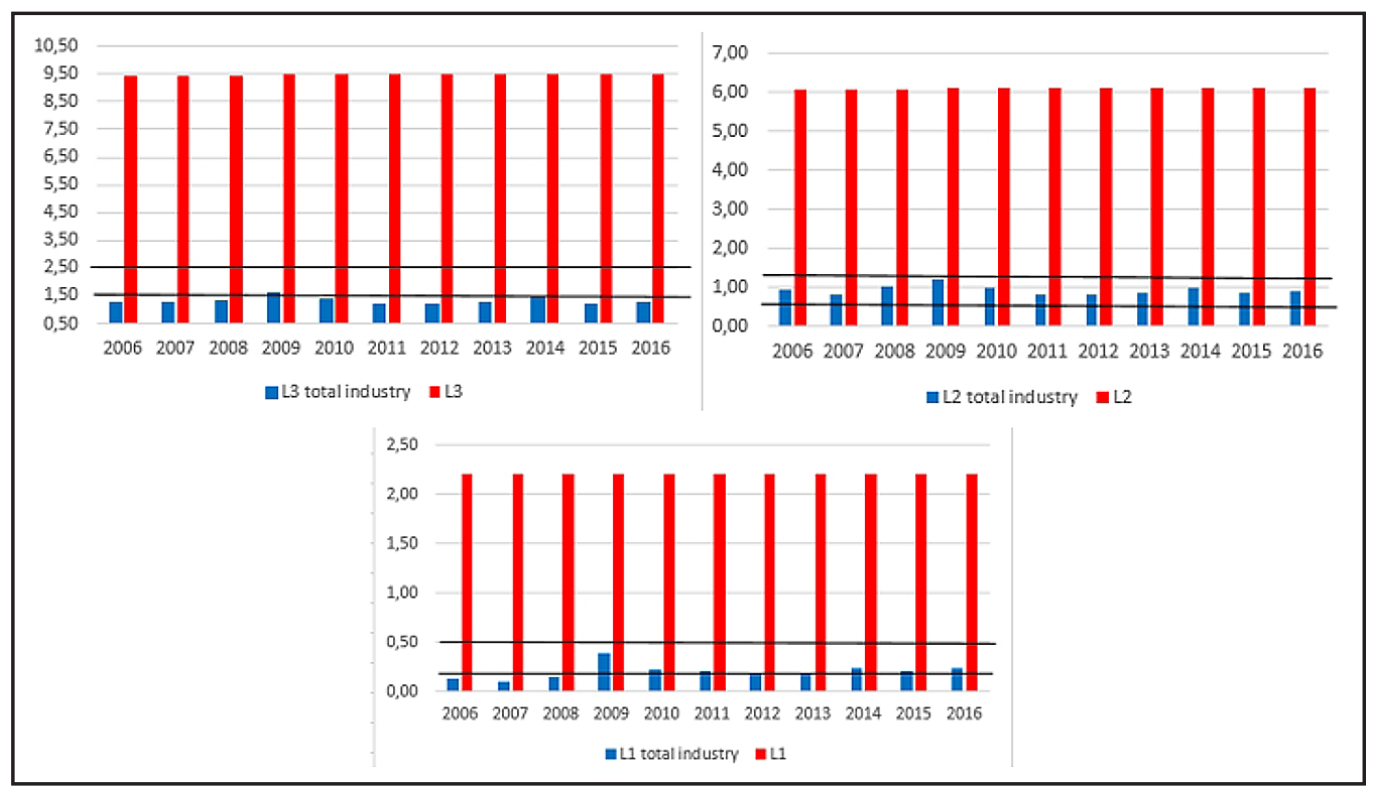

Sources: own processing from Amadeus database and Ministry of Industry and Trade of the Czech Republic

Figure 1: Development of liquidity indicators in the food industry in the Czech Republic from 2006 to 2016.

\begin{tabular}{|l|c|c|c|c|c|}
\hline & Short-term loans & Long-term loans & Debt equity ratio & $\begin{array}{c}\text { Other current } \\
\text { liabilities }\end{array}$ & $\begin{array}{c}\text { Other non- } \\
\text { current liabilities }\end{array}$ \\
\hline Cash liquidity (L1) & $-0.1981 *$ & -0.0221 & $-0.3443 *$ & $-0.3630 *$ & $-0.0741 * *$ \\
\hline Quick liquidity (L2) & $-0.0535 * * *$ & $-0.0722 * *$ & $-0.5051 *$ & $-0.5337 *$ & $-0.0867 *$ \\
\hline Current liquidity (L3) & -0.0180 & $-0.0782 * *$ & $-0.5132 *$ & $-0.5479 *$ & $-0.0939 *$ \\
\hline
\end{tabular}

Note: $*$ denotes significance at $1 \%$ level, $* *$ denotes significance at $5 \%$ level, $* * *$ denotes significance at $10 \%$ level

Source: authors' calculations

Table 4: Correlation between liquidity and debt funding sources structure. 
force towards neutral correlation. This means that if there is a rise in short-term loans, debt ratios, other current liabilities and other non-current liabilities, there will be a rise in cash liquidity. The correlation between the cash liquidity and the long-term loans indicator was not statistically significant.

Furthermore, the negative very weak correlation between the quick liquidity and the short-term loans, long-term loans and other non-current liabilities was demonstrated at a statistical significance level of $1 \%, 5 \%$ and $10 \%$. Within the debt equity ratio, other current liabilities and quick liquidity, the negative mean correlation strength was demonstrated. We can say that the decline in the debt financing sources structure will have an impact on the growth of quick liquidity. The correlation coefficient showed a negative very low correlation strength between current liquidity and long-term loans and other non-current liquidity at $1 \%$ and $5 \%$ level of statistical significance. On the contrary, the negative average correction force has been demonstrated between current liquidity and current liquidity and other current liabilities. Similarly, the decline in these indicators will trigger the growth of current liquidity.

Using correlation analysis we found out whether there is a linear correlation dependence between two variables. However, we are not able o determine which variable affects another variable. Using a Granger causality test, you can determine the direction in which the variables analyzed are mutually affected (Table 5).

\begin{tabular}{|c|c|c|}
\hline Granger causality test & F-Statistic & Probability \\
\hline DER $\neq>\mathrm{L} 1$ & 49.7244 & $2.00 \mathrm{E}-12$ \\
\hline $\mathrm{L} 1 \neq>\mathrm{DER}$ & 12.4812 & 0.0004 \\
\hline $\mathrm{STL} \neq>\mathrm{L} 1$ & 4.96532 & 0.026 \\
\hline $\mathrm{L} 1 \nRightarrow>\mathrm{STL}$ & 3.33838 & 0.0679 \\
\hline $\mathrm{L} 1 \neq>\mathrm{ONCL}$ & 2.77996 & 0.0956 \\
\hline $\mathrm{OCL} \neq>\mathrm{L} 1$ & 62.9391 & $3.00 \mathrm{E}-15$ \\
\hline $\mathrm{L} 1 \neq>\mathrm{OCL}$ & 18.4305 & $2.00 \mathrm{E}-05$ \\
\hline $\mathrm{DER} \neq>\mathrm{L} 2$ & 54.0902 & $3.00 \mathrm{E}-13$ \\
\hline $\mathrm{L} 2 \neq>$ DER & 4.22397 & 0.04 \\
\hline LTL $\neq>\mathrm{L} 2$ & 9.75569 & 0.0018 \\
\hline $\mathrm{L} 2 \not>\mathrm{LTL}$ & 4.31988 & 0.0379 \\
\hline $\mathrm{L} 2 \neq>\mathrm{ONCL}$ & 4.51687 & 0.0337 \\
\hline ONCL $\neq>\mathrm{L} 2$ & 47.5419 & $7.00 \mathrm{E}-12$ \\
\hline $\mathrm{DER} \neq>\mathrm{L} 3$ & 40.5843 & $2.00 \mathrm{E}-10$ \\
\hline $\mathrm{L} 3 \neq>\mathrm{DER}$ & 3.58992 & 0.0583 \\
\hline
\end{tabular}

Source: authors' calculations

Table 5: Granger causality test between liquidity and debt funding sources structure (to be continued).

\begin{tabular}{|l|c|c|}
\hline Granger causality test & F-Statistic & Probability \\
\hline L3 $\neq>$ LTL & 5.52193 & 0.019 \\
\hline STL $\neq>$ L3 & 5.83457 & 0.0159 \\
\hline L3 $\neq>$ ONCL & 3.01005 & 0.0829 \\
\hline OCL $\neq>$ L3 & 30.5883 & $4.00 \mathrm{E}-08$ \\
L3 $\neq>$ OCL & 3.52476 & 0.0606 \\
\hline
\end{tabular}

Source: authors' calculations

Table 5: Granger causality test between liquidity and debt funding sources structure (continuation).

Based on the results of the Granger Causality test, the double bond relationship between the debt equity ratio and the cash liquidity, shortterm loans and cash liquidity, other current liabilities and cash liquidity has been demonstrated. As part of the unilateral bond, the effect of cash liquidity on other non-current liabilities was demonstrated. Any change in debt equity ratio and short-term loans will affect cash liquidity of food companies. Conversely, if there is a change in cash liquidity, debt equity ratio, short-term loans and other non-current liabilities will also change. With regard to quick liquidity, the mutual influence of debt equity ratio, long-term loans and other non-current liabilities on quick liquidity has been demonstrated. Changing these indicators will impact quick liquidity and vice versa.

In addition, the impact of the debt ratio, shortterm loans and other current liabilities on current liquidity was demonstrated. If these indicators change, this change will also reflect current liquidity. Within current liquidity, its impact on the debt equity ratio, long-term loans, other current liabilities and other non-current liabilities has also been demonstrated. However, it should be noted that within the Granger causality, the test plays an annual delay role, where any change in the debt financing sources structure will be reflected in the company's liquidity with annual delays, and vice versa.

Using a Granger causality test, the direction in which the variables to be analysed could be influenced. However, we are not able to determine the causal relationship between the variables and determine the dependence of the endogenous variable on the exogenous variables. For this reason, the above methods were extended by the Generalized Method of Moments (GMM method) (Table 6).

The results of the GMM method showed the positive effect of long-term loans on cash liquidity (coefficient +0.0615 ) on a statistical significance level of $5 \%$. This means that 


\begin{tabular}{|l|c|c|c|c|c|c|c|}
\hline & $\begin{array}{c}\text { Delayed } \\
\text { variable }\end{array}$ & $\begin{array}{c}\text { Short term } \\
\text { loans }\end{array}$ & $\begin{array}{c}\text { Long term } \\
\text { loans }\end{array}$ & $\begin{array}{c}\text { Debt equity } \\
\text { ratio }\end{array}$ & $\begin{array}{c}\text { Other } \\
\text { current } \\
\text { liabilities }\end{array}$ & $\begin{array}{c}\text { Other } \\
\text { non-current } \\
\text { liabilities }\end{array}$ & J-statistic \\
\hline Cash liquidity (L1) & $\mathbf{1 . 0 1 0 5 *}$ & -0.0466 & $\mathbf{0 . 0 6 1 5 * *}$ & 0.0767 & $\mathbf{- 0 . 5 2 3 3 *}$ & -0.0286 & 127.3720 \\
\hline Quick liquidity (L2) & $\mathbf{1 . 2 5 6 4 *}$ & 0.0112 & $\mathbf{0 . 0 1 5 5 * *}$ & 0.0437 & $\mathbf{- 0 . 2 6 3 5 *}$ & 0.0028 & 88.28076 \\
\hline Current liquidity (L3) & $\mathbf{1 . 3 4 2 2 *}$ & 0.0064 & 0.0087 & 0.0104 & $\mathbf{- 0 . 1 8 9 4 *}$ & 0.0099 & 73.27072 \\
\hline
\end{tabular}

Note: $*$ denotes significance at $1 \%$ level, $* *$ denotes significance at $5 \%$ level, $* * *$ denotes significance at $10 \%$ level

Source: authors' calculations

Table 4: Correlation between liquidity and debt funding sources structure.

the growth of long-term loans will affect the growth of cash liquidity in food companies. In the case of higher debt, companies can use the tax shield that companies can use to their advantage. Companies can make money in the form of long-term loans to finance their activities or to invest in more profitable projects, which will then yield a higher yield than the cost of external financing in the form of long-term loans. Increasing indebtedness of companies in the food industry is also a risk for their creditors, especially agricultural primary production, which records long-term receivables from these companies. Table 5 shows that the positive effect of long-term loans $(+0.155)$ on quick liquidity on the level of $5 \%$ of statistical significance has been demonstrated. If a company tends to become more indebted, quick liquidity will occur. These results correspond to the cash liquidity results, where a similar effect of long-term loans to quick liquidity has occurred. This is in line with Baskin (1987), which concluded that companies with higher debt would accumulate liquidity because of the higher probability of financial distress. Also, Sufi (2009) found that companies that have significantly reduced access to credit have a particularly greater chance of saving cash from cash flows. This savings can be achieved by using a so-called tax shield, which can be seen as one of the benefits of taking credit from a company. Morellec (2001), who believes that companies are in debt because of the aforementioned tax shield, which companies can use to their advantage, is in support of this claim. In his research, Anderson (2002) believed that if a company relies on a high level of debt financing for a long time, it tends to have a high level of liquid assets. This fact leads the author to identify a potential link where a high level of debt leads to high liquidity, which in turn will lead to a slow growth of the company. This resulting relationship is in line with the presence of a proprietary liquidity holding motive for companies that maintain a high level of debt as a permanent feature of their capital structure. Šarlija and Harc (2012) also believe that long-term debt companies have more liquid assets and can be considered more liquid.

Furthermore, the negative effect of other current liabilities on cash liquidity $(-0.5233)$ on the statistical significance level was $1 \%$. If there is a decline in other current liabilities, there will be cash liquidity growth and vice versa. Other current liabilities include mainly payables to suppliers. In the case of companies in the food industry, they play a significant role in the obligations towards suppliers, especially agricultural holdings. At the level of statistical significance of $1 \%$ the negative impact of other current liabilities on quick liquidity (-0.2635) was confirmed. Growth of other current liabilities will lead to a reduction in quick liquidity. Within current liquidity, the negative effect of other current liabilities on current liquidity (- 0.1894$)$ was confirmed at $1 \%$ of the level of statistical significance. If there is an increase in unpaid liabilities, the current liquidity will decrease. This is in line with Ferreira and Vilela (2004), who suggest that companies with a high level of debt funds are less able to dispose of a high volume of highly liquid assets. Thus, the authors concluded that there is a negative link between debt sources of funding and the holding of highly liquid funds. Kim, Mauer and Sherman (1998) have shown a negative relationship between foreign resources and corporate liquidity in their study. Opler, Pinkowitz, Stulz, and Williamson (1999) also found similar results in their study, using a panel regression analysis to demonstrate a negative relationship between debt sources and corporate liquidity. Furthermore, the negative relationship between short-term debt resources and liquidity was demonstrated. This is because short-term debt assets and liquid assets can be a substitute in that a company facing low cash flow will respond to this either by drawing disposable liquid assets or by accumulating short-term foreign resources or a combination of both. Šarlija and Harc (2012), using Pearson's correlation coefficient, demonstrated the existence of a negative relationship 
between corporate liquidity and foreign funding sources. The authors of the study also concluded that the negative relationship between company liquidity and short-term foreign sources is more significant than the positive relationship between company liquidity and long-term debt sources.

The statistical significance of the results found is the J-statistic (127.3720 for cash liquidity, 88.28076 for quick liquidity, 73.27072 for current liquidity), which confirms the robustness of all three models. The effect of the other variables analysed was not statistically significant.

Using the generalized method of moments (GMM method), indicators have been identified that affect the liquidity of companies in the food industry. Research results have shown that this is an indicator of long-term loans and other current liabilities. These two indicators have the most significant impact on the company's liquidity management. Long-term loans represent the most risky loans for banks, therefore they are provided under very strict conditions. Credit risk corresponds to higher interest rates as compared to short-term loans. For businesses, however, the advantage of long-term loans lies in lower payment, which are paid over a longer period of time. Therefore, businesses are not burdened with a high outflow of funds due to a high repayment. The food industry is considered to be a diversified, largely high-turnover industry that uses long-term bank loans to further capitalize on cash. If we focus on the food industry as a whole (Figure 1), we can see that these food companies have achieved uniform liquidity values throughout the analysis period. There was only a minor fluctuation in 2009 due to the effects of the financial crisis. In general, however, the industry is not experiencing significant liquidity problems, but in many cases it is above average compared to the recommended liquidity values. The food industry is characterized by a higher level of current assets, leading to the liquidity of companies operating in the food industry. Long-term bank loans that secure the business of these companies contribute to liquidity. On the other hand, if other short-term liabilities continue to grow for these companies, this will probably jeopardize their liquidity position. An important role here is the turnover time of the commitment, which shows how long the company is able to pay its short-term liabilities. If a company pays its liabilities at longer time intervals, it means that the company rewards its money before the maturity date of its liabilities in other more profitable investments. On the other hand, this may also mean that the company has liquidity problems and is unable to pay its liabilities properly and on time.

Other current liabilities include mainly unpaid invoices, unpaid wages or unpaid taxes. Without any other current liabilities, no company can practically fail. Naturally, they arise from the normal operation of the company and from repeated business relations. Typically, they are financed by circulating assets or other operating needs. The volume of short-term capital is affected by the amount of working capital (current assets minus current liabilities) and liquidity. At the level of $1 \%$ of statistical significance, the positive ratio of the cash ratio, quick ratio, current ratio to the cash ratio, quick ratio and current ratio of the current year was shown. This means that the rise in the cash ratio, quick ratio and current ratio of the previous period increases the values of the cash ratio, quick ratio and current ratio of the current period.

\section{Conclusion}

The food industry as part of the manufacturing industry includes not only the production of food products but also the production of beverages. According to the Ministry of Agriculture (2004), the food sector, as a key element of this industry, will ensure the daily food supply of the food market. From the point of view of the standard of living, this is an important part of a consumer market with strategic importance expressing national interest that becomes urgent in crisis situations such as natural disasters etc.

The aim of this article was to determine the impact of debt funding sources structure on liquidity of companies in food industry in the Czech Republic from 2006 to 2016. With the purpose to fulfill the aim, we examined existence and character of relationship between the debt funding sources structure (long-term loans, short-term loans, other long-term liabilities, other short-term liabilities, debt equity ratio) and liquidity of the companies in food industry in the Czech Republic. The relationship between debt funding sources structure and liquidity of companies was tested through correlation analysis, Granger causality test and generalized method of moments (GMM).

The results showed that it is important for companies in the food industry to track the volume of long-term loans and the volume of other current-liabilities. The results confirmed that long-term loans have a positive effect on the cash ratio and quick ratio. 
The resulting coefficients are +0.0615 for cash liquidity and +0.0155 for quick liquidity. This means that if the long-term bank loans increase by 1 unit, the cash liquidity value increases by 0.0615 units and the quick liquidity value by 0.0155 units. The results also confirmed the negative impact of other current liabilities on the cash ratio, the quick ratio and the current ratio. The resulting coefficients are - 0.5233 for cash liquidity, - 0.2635 for quick liquidity and -0.1894 for current liquidity. This means that if other current liabilities increase by 1 unit, the cash liquidity value drops by 0.5233 units, the quick liquidity value drops by 0.2635 units and the current liquidity drops by 0.1894 units. If the company's indebtedness is regularly monitored, the amount of the owed amount will be fully controlled by the company and the borrowed funds will be used appropriately in the production process, it will have a positive impact on corporate liquidity. On the other hand, if there is a constant increase in other current liabilities, this will reduce corporate liquidity.

The conclusion can be said, as stated by the Institute of Agricultural Economics and Information (2017), the production of food products in the Czech Republic belongs to the major branches

\section{Corresponding authors}

Ing. Markéta Šeligová, Ph.D., assistant professor

Silesian University in Opava, School of Business Administration in Karvina

Univerzitní náměstí 1934, 73340 Karviná, Czech Republic

Email: seligova@opf.slu.cz

\section{References}

[1] Ahn, S., Denis, D. and Denis, D. (2006) "Leverage and investment in diversified firms", Journal of Financial Economics, Vol. 79, No. 2, pp. 317-337. ISSN 0304-405X. DOI 10.1016/j. jifineco.2005.03.002.

[2] Anderson, R. W. (2002) "Capital structure, firm liquidity and growth", Working papers research series. National Bank of Belgium. [Online]. Available: www.nbb.be/doc/ts/publications/wp/ WP27en.pdf. [Accessed: 1 Feb. 2017].

[3] Andrade, G. and Kaplan, S. (1998) "How costly is financial (not economic) distress? Evidence from highly leveraged transactions that become distressed“, Journal of Finance, Vol. 53, pp. 1443-1493. ISSN 1540-6261.

[4] Almeida, H., Campello, M. and Weisbach, S. M. (2004) "The cash flow sensitivity of cash“, Journal of Finance, Vol. 59, pp. 1777-1804. ISSN 1540-6261. DOI 10.1111/j.1540-6261.2004.00679.x.

[5] Al-najjar, B. and Belghitar, Y. (2011) "Corporate cash holdings and dividend payments: Evidence from simultaneous analysis“, Managerial and Decision Economics, Vol. 32, No. 4, pp. 231-241. ISSN 1099-1468. DOI 10.1002/mde.1529.

[6] Baskin, J. (1987) "Corporate Liquidity in Games of Monopoly Power“, The Review of Economics and Statistics, Vol. 69, No. 2, pp. 312-319. ISSN 1530-9142. DOI 10.2307/1927239. 
[7] Campello, M. (2003) "Capital structure and product markets interactions: evidence from business cycles“, Journal of Financial Economics, Vol. 68, pp. 353-378. ISSN 0304-405X. DOI 10.1016/S0304-405X(03)00070-9.

[8] Campello, M. and Fluck, Z. (2005) "Product Market Performance, Switching Costs, and Liquidation Values: The Real Effects of Financial Leverage“, University of Illinois. Working paper.

[9] Cohen, J. and Cohen, P. (2014) “Applied Multiple Regression/Correlaion Analysis for the Bevaioral Sciences“, $2^{\text {nd }}$ ed., Psychology Press. ISBN 0-89859-268-2.

[10] Eisdorfer, A. (2008) "Empirical evidence of risk-shifting in financially distressed firms", Journal of Finance, Vol. 63, pp. 609-637. ISSN 1540-6261. DOI 10.2139/ssrn.686435.

[11] Engle, R. F. and Granger, W. C. (1987) "Co-integration and Error Correction: Representation, Estimation, and Testing“, Econometrica, Vol. 55, No. 2, pp. 251-276. ISSN 1468-0262. DOI $10.2307 / 1913236$.

[12] Evans, J. D. (1996) "Straightforward statistics for the behavioral sciences", Pacific Grove, CA: Brooks/Cole Publishing Company. ISBN 978-0534231002.

[13] Ferreira, A. and Vilela, S. (2004) "Why do firms hold cash? Evidence from EMU Countries", European Financial Management, Vol. 10, No. 2, pp. 295-319. ISSN 1468-036X. DOI 10.1111/j.1354-7798.2004.00251.x.

[14] Graham, J. (2000) "How big are the tax benefits of debt?", Journal of Finance, Vol. 55, pp. 1901-1941. ISSN 1540-6261. DOI 10.1111/0022-1082.0027.

[15] Hall, A. R. (2005) "Generalized Method of Moments (Advanced Texts in Econometrics)“, Oxford: University Press. ISBN 0-19-877521-0.

[16] Institute of Agricultural Economics and Information (2017) "Panorama of the Food Industry 2016", Prague: Ministry of Agriculture. ISBN 978-80-7434-387-2.

[17] Kim, C. S., Mauer, D. C. and Sherman, A. E. (1998) "The determinants of corporate liquidity: Theory and evidence“, Journal of Financial and Quantitative Analysis, Vol. 33, No. 3, pp. 335-359. ISSN 0022-1090. DOI 10.2307/2331099.

[18] Mehar, A. (2005) "Impacts of equity financing on liquidity position of a firm", Applied Financial Economics, Vol. 15, pp. 425-438. ISSN 1756-6916. DOI 10.1080/0960310042000314197.

[19] Miloş, M. C. (2015) "Capital Structure Determinants. Evidence from the Romanian Listed Companies", Analele Universitatii 'Eftimie Murgu' Resita, Fascicola II. Studii Economice, pp. 129-134. ISSN 1584-0972.

[20] Ministry of Agriculture (2014) "The concept of food industry in the Czech Republic for the period after the accession of the Czech Republic to the EU (2004-2013)“, [Online]. Available: http://eagri.cz/public/web/file/3045/_16452_32655_Koncepce_potravinarstvi_2004_2014_1_. pdf. [Accessed: 28 July 2018].

[21] Morellec, E. (2001) "Asset liquidity, capital structure, and secured debt", Journal of Financial Economics, Vol. 61, pp. 173-206. ISSN 0304-405X. DOI 10.1016/S0304-405X(01)00059-9.

[22] Opler, T., Pinkowitz, L., Stulz, R. and Williamson, R. (1999) "The determinants and implications of corporate cash holdings", Journal of Financial Economics, Vol. 52, No. 1, pp. 3-46. ISSN 0304-405X. DOI 10.1016/S0304-405X(99)00003-3.

[23] Peyer, U. and Shivdasani, A. (2001) "Leverage and internal capital markets: evidence from leveraged recapitalizations“, Journal of Financial Economics, Vol. 59, pp. 477-516. ISSN 0304-405X. DOI 10.1016/S0304-405X(00)00094-5.

[24] Prucha, I. R. (2014) "Instrumental Variables/Method of Moments Estimation“, In: Fisher, M. M. and Nijkamp, P. eds. "Handbook of Regional Science", Heidelberg: Springer. ISBN 978-3-642-23430-9. DOI 10.1007/978-3-642-23430-9_90. 
[25] Růčková, P. (2014) “Vztah rentability, likvidity a hrubého domácího produktu v podmínkách České republiky“, Český finanční a účetní časopis, Vol. 1, pp. 140-147. ISSN 1802-2200. (In Czech). DOI 10.18267/j.cfuc.388.

[26] Růčková, P. (2015) "Vliv likvidity a rentability na využití zdrojů financování ve zpracovatelských podnicích v zemích V4“, Acta academica karviniensia, Vol. 15, No. 3, pp. 69-79. ISSN 1212-415X. DOI 10.25142/aak.2015.032.

[27] Shah, P. (2012) "Evaluation of Profitability and Liquidity Relationship through Multivariate Working Capital Analysis“, A Management Journal, Vol. 3, No. 2, pp. 177-198. ISSN 0378-7206.

[28] Stulz, R. (1990) "Managerial discretion and optimal financing policies", Journal of Financial Economics, Vol 26, No. 1, pp. 3-27. ISSN 0304-405X. DOI 10.1016/0304-405X(90)90011-N.

[29] Sufi, A. (2009) "Bank lines of credit in corporate finance: an empirical analysis", Review of Financial Studies, Vol. 22, No. 3, pp. 1057-1088. ISSN 1465-7368. DOI 10.1093/revfin/hhm007.

[30] Šarlija, N. and Harc, M. (2012) "The impact of liquidity on the capital structure: a case study of Croatian firms", Business Systems Research, Vol. 3, No. 1, pp. 30-36. ISSN 1847-9375. DOI 10.2478/v10305-012-0005-1.

[31] Šeligová, M. (2017) "The Effect of Selected Financial Indicators on Liquidity of Companies in Selected Sectors in the Czech Republic", Acta Universitatis Agriculturae et Silviculturae Mendelianae Brunensis, Vol. 65, No. 6, pp. 2085-2091. ISSN 1211-8516. DOI 10.11118/actaun201765062095.

[32] Šeligová, M. (2018) "The Impact of Funding Sources on Corporate Liquidity in Energy Sector in the Czech Republic and Slovak Republic", Scientific Papers of the University of Pardubice - Series D, Vol. 25, No. 42, pp. 223-234. ISSN 1804-8048. DOI 10.3846/cbme.2017.116.

[33] Trippner, P. (2013) "Analysis of Financial Liquidity Management in the Enterprise and its Impact on the Profitability“, In: Stavárek, D. and P. Vodová (ed). In: Proceedings of $14^{\text {th }}$ International Conference on Finance and Banking. Karviná: Silesian University, School of Business Administration, pp. 494-501. ISBN 978-80-7248- 939-8. 